\title{
AJRC
}

Australia - Japan Research Centre

\section{Do Japanese MNCs use Expatriates to Contain Risk in Asian Host Countries?}

\section{AJRC Working Paper 02/2015 March 2015}

\section{Jean-Pascal Bassino}

Department of Social Sciences

Ecole Normale Supérieure de Lyon

\section{Marion Dovis}

Aix-Marseille School of Economics (Aix-Marseille University)

CNRS \& EHESS

\section{Pierre van der Eng}

Research School of Management

ANU College of Business and Economics

Australian National University

\section{Abstract}

We investigate the impact of host country risk on the expatriation strategies of multinational firms, using data on Japanese subsidiary firms in manufacturing industry in 13 host countries in Asia. We find that country risk is negatively correlated with the degree of expatriation and that, rather than host country risk, firm-specific factors (particularly capital intensity, ownership share of parent firms in subsidiaries and the age of the venture) explain most of the variation in the degree to which subsidiaries rely on Japanese expatriates. Contrary to previous studies, the capital intensity of production is a key explanatory firm-specific variable that correlates positively with the degree of expatriation. Japanese MNCs do not rely on expatriates to off-set host country risk, but to mitigate risk to parent investment in subsidiaries. 


\section{Keywords}

Expatriates, Foreign Direct Investment, Multinational Companies, Country Risk, Japan, Asia

\section{JEL Classification}

G32, M12, M16, N85

\section{Suggested Citation:}

Bassino, J.P, Dovis, M., van der Eng, P., 2015. AJRC Working Paper No. 2, November 2015. Australia-Japan Research Centre, Crawford School of Public Policy, The Australian National University.

\section{Address for correspondence:}

(E) ajrc@anu.edu.au

ISSN 07288409

ISBN 978-0-86413-012-9

The Australia-Japan Research Centre (AJRC) conducts research to explore and improve understanding of the economies and economic policy processes in Australia and Japan and both countries' strategic interests in the Asia Pacific economy.

The AJRC Working Paper Series aims to provide a forum for the exchange of topical research and contains the latest research and analysis on the Japanese economy, as well as the political economy, regional integration and trade. The views expressed in AJRC Working Papers are those of the individual authors and do not represent the views of the Australia-Japan Research Centre, the Crawford School, or the institutions to which authors are attached.

The Crawford School of Public Policy is the Australian National University's public policy school, serving and influencing Australia, Asia and the Pacific through advanced policy research, graduate and executive education, and policy impact. 


\section{Introduction}

The expatriation or localisation of management of foreign subsidiaries of multinational companies (MNCs) has been the subject of ongoing research in international business since at least the mid1970s. Such research is pertinent, as firms need to determine what expatriate staffing levels are appropriate for their subsidies, given the cost of selecting, training and maintaining expatriate managers, as well as the cost of expatriate failure. Available studies have probed the issue in various ways, but are yet to yield consensus about the factors that determine the choice by MNCs to dispatch expatriate managers to subsidiary firms or depend on locally recruited senior staff.

In essence, the choice between expatriation and localisation is considered in two ways. The 'coordination and control' approach considers that internationalisation of a company's activities involves transplanting some core capabilities and practices from the parent firm to subsidiaries (e.g. Boyacigiller 1990; Watson O'Donnell 2000). If these capabilities require close scrutiny by the parent, internationalisation may imply the relocation of experienced managers from the parent for the purpose of overseeing the transplantation and ongoing implementation of the core capabilities in the foreign subsidiary. An advantage is that expatriates are familiar with the organisation and strategy of the MNC, and steeped in the MNC's corporate culture. They may be better able to keep the objectives of the foreign subsidiary aligned with those of the parent, allowing the parent to avoid any dangers of opportunistic behaviour by a local joint-venture partner.

Other studies regard the engagement of expatriate managers as a transitory but necessary phase in the development of a foreign subsidiary. Subsidiaries depend in their initial stages on the transmission of core capabilities and practices from their parents, and expatriate managers perform an important facilitating role in that process (e.g. Downes and Thomas 2000; Kawai and Strange 2014). This 'transitory phase' approach argues that expatriates (and their families) tend to be costly to maintain, while the cost of expatriate failure can be considerable. As a subsidiary gains experience in the business environment of a host country, the parent is likely to localise subsidiary management. Advantages of localising management include in-depth knowledge of the business conditions in the host country that local managers tend to have, and the fact that they are less costly. In due time, MNCs may allow foreign subsidiaries to increase their engagement of locals in senior management positions, particularly after local managers have gained experience and familiarity with the international organisation and strategy, as well as the corporate culture of the parent. Given cost aspects, localisation of management in foreign subsidiaries may be more financially advantageous than maintaining a contingent of expatriates.

Despite a significant accumulation of studies analysing the degree of expatriation in subsidiary firms, there is no consensus on the fundamental factors that explain the choice between expatiation and localisation of management of foreign subsidiaries. Different methodologies (e.g. case studies, surveys, variance analysis) and data sets have yielded different outcomes, or outcomes that are difficult to generalise.

This paper focuses on an important common element in both strands of the literature, which is that MNCs commit valuable resources to their foreign subsidiaries and expose these to host country risk. The resources take the form of proprietary capabilities and practices, human resources, as well as financial resources in the form of investment in the production technologies used by subsidiaries and 
debt guarantees. Few relevant studies account for the commitment of financial resources. As far as they do, improperly account for the true value of committed capital, as the next section explains. Another drawback of existing studies is that they control for risks in the host country by using a composite of very broad general indicators of differences in the business environments of home and host countries, or country risk indicators that may be relevant to portfolio investors, but not necessarily to MNCs that can 'unpack' country risk and respond to the different host country risk elements they perceive relevant to protecting the resources they commit to their foreign subsidiaries.

It can be hypothesised that MNCs with considerable investments in foreign subsidiaries seek to minimise the risk to that investment by maximising the returns on the core capabilities engaged in subsidiaries, and possibly by aligning the objectives of the subsidiary with those of the parent firm. A relatively high number of home country expatriates in key management positions may be a means to that end. Hence, variation of the degree of expatriation needs to strike a balance between explanatory factors that are specific to the subsidiary firm and the host-country. This paper analyses this issue on the basis of a large database containing firm-level data for Japanese subsidiary firms in other Asian countries and territories. These host countries were chosen in order to minimise the possible impact of cross-cultural differences between the host countries on expatriation. The study also focuses on manufacturing firms in order to minimise the possible consequences of the fact that Japanese subsidiary firms are active across host countries in different combinations of industries.

\section{Literature Review}

The study of the expatriation strategies of MNCs is dominated by issues of international human resource management, particularly recruitment practices, and the risk/cost to the firm of expatriates failing (e.g. Selmer 1995; Baruch and Altman 2002). Early studies seeking to explain the choice between expatriation and localisation were considerably hampered by the availability of data. For instance, Boyacigiller (1990) and Downes and Thomas (2000) base their arguments on expatriation in the subsidiaries of just one firm. More recent research relies on case studies or country studies. The number of cases in a study is often limited, which makes it difficult to generalise the findings.

During the last 15 years, several studies have started to use large firm-level data sets, combining them country-level data for home and host countries to explain variations in the degree of expatriation of subsidiary companies (e.g. Gaur, Delios, and Singh 2007). This would be appropriate if the combination of home country firms across all host countries is broadly similar and therefore comparable. But this is never the case, as firms from the same home country are attracted to a host country for a range of different reasons. In other words, the 'average home country firm' does not exist. It therefore remains unclear whether the specifics of parent and subsidiary firms, rather than the specifics of home and host countries explain the degree of expatriation in subsidiaries of MNCs across host countries.

Several empirical studies analyse expatriation by Japanese firms (e.g. Konopaske, Werner and Neupert 2002; Gong 2003; Paik and Sohn 2004; Belderbos and Heijltjes 2005; Tan and Mahoney 2006; Gaur, Delios, and Singh 2007; Wilkinson, Peng, Brouthers, and Beamish 2008; Fang et al. 2010; Widmier, Brouthers, and Beamish 2010; Peng and Beamish 2014; Ando and Paik 2014). A few take account of parent investments in subsidiary firms, but fail to account for the true value of committed capital by correcting for inflation since the year of establishment, which consequently leads 
them to conclude that capital investment is not a significant explanatory variable (e.g. Widmier et al. 2008, 1616; Fang et al. 2010, 43), or that capital was marginally significant as an explanatory variable and negatively correlated with the degree of expatriation (Gaur, Delios and Singh 2007, 625 and 627). In addition, these studies do not account for the fact that competing firms in different industries are able to apply a range of different technologies to produce similar goods, ranging e.g. from labourintensive to capital-intensive technologies. Relative factor prices in host countries are likely to be an important determinant of the choice of technology along the production frontier, but individual firms also have other reasons to select a specific technology, which therefore require an eclectic approach to explaining the choice of technology, as Chen (1983) explains. An element in this 'choice of technology' literature is the fact that a firm's choice for a higher capital intensity of production (as indicated by the ratio of capital and employment) necessarily requires a greater commitment of financial resources.

A further drawback of relevant multi-country studies is that they control for risks in the host country on the basis of broad composite indicators of differences in the business environments of host countries that are assumed to be proxies of risk. These are generally composite country risk indicators obtained from readily available sources such as Euromoney, Institutional Investor or Political Risk Yearbook and designed for analysis of portfolio investments (e.g. Click 2005). Using such indicators ignores the subjectivity underlying them, due to the choice and weighting of the underlying variables and can therefore be misleading, as Oetzel, Bettis, and Zenner (2001) argue. More recently, studies have started to use similar indicators of 'institutional distance' between home and host countries, which suffer from similar drawbacks related to variable selection and weighting, as Zaheer, SpringSchomaker and Nachum (2012) argue.

More importantly, these indicators are at best suited to analysing the decisions of portfolio investors who have few opportunities to hedge perceived country risks, and a broad-based indicator may suffice for them. But in the case of foreign direct investment (FDI), MNCs are in a position to 'unpack' country risk and respond to the different risk elements they perceive relevant to their foreign subsidiaries in order to protect the resources they commit to foreign subsidiaries. They can strategically shape subsidiary ventures, e.g. through the choice of joint venture (JV) partners, the share of their commitment in the subsidiary, the choice of technology, expatriation, as well as embedding a subsidiary in the business environment of the host country etc. Hence, using composite indicators of country risk or institutional distance between home and host countries may not adequately contribute to the analysis of expatriation by MNCs engaged in FDI.

Japanese MNCs rely to a higher degree on expatriates in key management positions of their foreign subsidiaries, compared to MNCs from other countries (Keeley 2001, 115-20; Yoshihara 2005: 244246; Jaussaud and Schaaper 2007: 236-238). For example, in 1998, 72\% of Japanese subsidiary manufacturing firms in Asia had a Japanese national as top executive, significantly higher than US and European firms (METI 2003: 160-161). This phenomenon has been related to the particular human resource management practices of Japanese firms (e.g. Beechler and Yang 1994). It has also been related to the idea that Japanese firms replicated keiretsu structures in other countries, requiring intensive intra-firm communications with headquarters in Japan and inter-firm communications with keiretsu-associated Japanese subsidiaries in host countries and therefore Japanese expatriates in senior positions (e.g. Yoshihara 2005: 247-249; Yoshihara 2008: 7-9). Shiraki (2007: 9-10) found that the need for subsidiaries to coordinate with headquarters in Japan as well as the need for the 
'penetration of the management principles/methods' of headquarters in Japan to be the main reasons. Legewie (2002) argues that a prevailing innate 'insider-outsider mentality' prevents Japanese firms from localising the management of their subsidiaries, while many Japanese firms in China are resource rather than market-seeking and do not require the local feedback that senior local managers can generate.

Even though Japanese subsidiary firms depend to a large extent on expatriates in senior positions, the variation in the degree to which the foreign subsidiaries of Japanese MNCs employ home country expatriates has not yet been fully explained. Several empirical studies have addressed this issue, but they arguably contain methodological limitations. For example, Belderbos and Heijltjes (2005) seek to explain the appointment of expatriate and local managers as managing directors (CEOs) of 844 subsidiary firms of Japanese electronics-producing companies in eight Asian countries in 1995. They find that the strategic dependence of a parent firm on the affiliate increased the propensity to appoint expatriates. However, (a) the study only analyses CEO appointments, which fails to account for the possibility that managing directors have been token appointments, as Yoshihara (2008: 6-7) explains, and that the appointment of Japanese expatriates in other senior management positions serves the purpose of maintaining control. ${ }^{1}$ (b) It takes the ratio of affiliate employees and employees of the parent firm as an indication of the size of the subsidiary firm, which does not take account of the capital intensity of production and thus the potential risk to the investment made by parent firms and their lenders.

Gaur, Delios, and Singh (2007) seek to explain the appointment of expatriate and local managers as general managers (i.e. CEOs) on the basis of the 'institutional distance' of the host country with Japan. They analyse the impact of that appointment on firm performance for almost 13,000 subsidiaries of Japanese firms in 48 countries in 2002 and find that a higher 'institutional distance' encourages firms to rely more on expatriates. This study (a) does not take account of the appointment of Japanese expatriates in other senior positions than CEO, possibly in order to offset the consequences of the appointment of a local CEO. (b) It creates composite country-level indicators of 'regulative' and 'normative' distance between Japan and the host country, but does not explain in detail what factors are included and how they are weighted. As explained above, the problem is that firms making FDIrelated decisions may utilise different combinations of ways to mitigate the potential negative consequences of distance. (c) It uses sales per employee as indicator of productivity. This is at best a proxy indicator of performance. Some firms have high sales/worker ratios because they depend to a high degree on purchased inputs, add little value themselves to the value of sales, and require a high turnover to generate sufficient net returns. This indicator also takes no account of the differences in capital intensity of production across different industries and therefore the differences in risk that parent firms experience as a consequence of the differences in the relative size of their investment.

Tan and Mahoney (2006) seek to explain variations in the ratio of expatriate managers and total employment in 284 subsidiaries of Japanese firms in the USA in 2000. They use a range of explanatory variables, several of which were industry-specific rather than firm-specific. While this study focuses on all expatriate employment in subsidiaries and not just the nationality of the CEO, it fails to account for the role of investment by parent firms in the subsidiaries. The control variable for firm size

\footnotetext{
${ }^{1}$ METI $(2003,160)$ shows for example that in 1998 not only $72 \%$ of top executives were Japanese expatriates, but also that $63 \%$ of deputy top executives and 31 to $68 \%$ of personnel in key functional departments in Japanese subsidiary manufacturing companies in Asia were Japanese expatriates.
} 
is employment and the joint-venture indicator is a simple dummy variable, rather than the share of the parent firm in a JV.

Wilkinson, Peng, Brouthers, and Beamish (2008) seek to explain variations in the ratio of expatriate managers and total employment in 5,296 subsidiaries of Japanese firms around the world in 2001, by focusing on 'cultural distance' between Japan and host countries. They find that 'cultural distance' enhances the rate of expatriation. Leaving difficulties of measuring and interpreting 'cultural distance' aside, their choice of control variables may skew the results of this study. While the study does not account for capital investment, several of the firm-level controls are actually more statistically significant than the indicators of 'cultural distance', which actually have low predictive power.

Ando and Paik (2013) offer a more involved explanation of variations in the ratio of expatriate managers and total employment in 2,980 subsidiaries of Japanese firms in 2008. Their approach includes parent firm characteristics, such their international experience, and they use the more relevant World Bank Governance indicators to define 'institutional distance'. They find a significant negative correlation between expatriation and 'institutional distance', but do not account for the size of subsidiaries, nor parent investment.

Lastly, Peng and Beamish (2014) seek to explain variations in the ratio of expatriate managers and total employment in 11,754 subsidiaries of Japanese firms during 1996-2005, by focusing on the size of subsidiaries and by also including parent firm characteristics in the analysis. However, they define subsidiary size simply as the number of employees, do not control for the size of parent firm capital investment - except the percentage equity ownership by parent firms - and approximate host country risk with credit ratings from Institutional Investor. For reasons explained above, such limitations may affect their findings.

\section{Theory and Hypotheses}

This brief discussion of the literature indicates that several issues require further research. One is that available studies tend to use only total employment as an indication of size of subsidiary firms. This fails to account for the fact that in several industries firms can choose from a range of production technologies in a continuum from labour-intensive to capital-intensive. For that reason, a clear distinction has to be made between firms according to the capital intensity of production, as Jaussaud, Schaaper, and Zhang (2001) suggest. It can be assumed that capital-intensive production requires a subsidiary company to rely on proprietary technology and the transfer of capabilities and practices from the parent MNC in order to be able to make optimum productive use of the technology. Another way to consider this is that capital-intensive production requires certainty that a subsidiary firm will be able to generate net income that allows it to service capital invested in its plant, whether in the form of parent-guaranteed debt or equity. It would not matter in this case whether the investment is large or small. The relevant issue is that invested capital needs to be serviced. Dependence on experienced expatriates may offer some guarantee to that effect.

Hypothesis 1: There is a positive relation between the capital intensity of a foreign subsidiary firm and the share of home country expatriates in total employment of that firm. 
Where parent firms engage local joint-venture partners in their foreign subsidiaries, the local partners may have expectations about the employment of locals in senior management positions. Either to acknowledge the valuable contribution of local partners to the joint-venture, or possibly for the purpose of mollifying local partners, parent firms may therefore agree to the engagement of local managers in senior positions. But where the role of local partners in a joint-venture is small, foreign parent firms may not be inclined to consider engaging such local managers.

Hypothesis 2: There is a positive relation between the ownership share of foreign parent firms in a foreign $\mathrm{JV}$ and the share of home country expatriates in total employment of that venture.

Many foreign subsidiaries may start as modest operations and then grow as they create and grasp opportunities, reinvesting profits to finance expansion. At the same time, senior expatriate managers of subsidiary firms may gain sufficient experience with the local business environment to understand the potential risks to the firm. A parent firm may then decide to utilise this experience in the form of supervision of the subsidiary from the home country, thus allowing local managers to subsume senior roles in the subsidiary firm. In addition, local junior managers may gain experience in the firm and trust from senior managers, before being promoted to senior positions. This is in essence the 'transitory phase' argument, as explained above.

Hypothesis 3: There is a negative relation between the age of the foreign subsidiary firm and the share of home country expatriates in total employment of that subsidiary.

An extension of both the 'coordination and control' and 'transitory phase' arguments is that engagement of expatriates in senior positions in a subsidiary firm is a response to elements of uncertainty in the business environment. These require the involvement of experienced managers who understand the operations of both parent firm and subsidiary and their markets, and who are able to draw on that experience to mitigate risk to the subsidiary firm. Their role may diminish and they may make way for local managers when the firm has developed ways to anticipate and accommodate risk. For example, Wilkinson, Peng, Brouthers and Beamish $(2008,99-101)$ find that host country risk was indeed positively correlated with the expatriation ratio. However, their choice of country credit ratings from Institutional Investor may be an imperfect indicator of country risk for the purpose of analysing MNC commitments to FDI.

Hypothesis 4: There is a negative relation between the perceived risk in a host country and the share of home country expatriates in total employment in a foreign subsidiary firm.

Formal testing of these hypotheses requires firm-level data that allow a comparison of like-with-like. For example, the capital intensity of production (Hypothesis 1) may be related to the level of technical sophistication in the industry of the firm. Hence, steel producing firms generally use widely established technologies and tend to increase their competitiveness by capturing scale economies, while semiconductor producing firms operate at a technological frontier and maintain their competitiveness by pushing it further out. In both cases, operations may be capital-intensive, but the required level of technical sophistication could be significantly higher in the second case, requiring expatriate managers for 'coordination and control', if not the protection of intellectual property. Hence, formal testing in principle needs to account for the industries in which subsidiary firms operate. 


\section{Methodology}

Quantitative firm-level data used in this paper were obtained from the annual Tōyō Keizai database containing data on Japanese subsidiary firms for each year $1999-2004 .{ }^{2}$ We compiled a subset with panel data for 13 Asian countries: South Korea, China, Hong Kong, Taiwan, Vietnam, The Philippines, Thailand, Malaysia, Singapore, Indonesia, India, Pakistan and Sri Lanka. These countries were selected in order to accommodate the impact of different levels of risk perceived by subsidiary firms and their parents on investment decisions in the analysis. ${ }^{3}$ In order to avoid possible outliers we cleaned the dataset. The initial number of observations was 29,977. We excluded all Japanese subsidiary firms without data on total and/or expatriate employment, as well as firms with zero or one employee, which generally were representative offices of Japanese manufacturing firms without manufacturing plants. We also eliminated subsidiaries without information on paid-up capital, and we left out firms that were included in the database for less than three consecutive years. Lastly, we rejected observations where capital or employment grew by more than $300 \%$ or decreased by more than $50 \%$ from one year to the next. The cleaned dataset comprised 26,048 observations. The following variables from the dataset were used: age, or the number of years since the establishment of the subsidiary firm; number of Japanese expatriate employees; total number of employees; number of Japanese joint-venture partners; paid-up capital, converted to US $\$$ in constant 2000 prices $^{4}$; share of Japanese parent firms in paid-up capital; share of local partners in paid-up capital.

The motivation for using shares of Japanese parent companies and of local partners in paid-up capital separately is that the total is not equal to $100 \%$. Older, established Japanese subsidiary companies in Hong Kong, Singapore and Taiwan (and in Thailand and Malaysia in later years) also contribute as investors and therefore as shareholders to financing the creation or expansion of new Japanese subsidiaries. This is explained to a large extent by the comparatively high level of corporate taxation in Japan that leads Japanese MNCs to rely on the cash flow available in foreign subsidiaries for the

\footnotetext{
${ }^{2}$ The database comprises the results of an annual survey undertaken by the Tōyō Keizai publishing company. It is published in Japanese as 海外進出企業総覧 (Kaigai Shinshutsu Kigyo Soran). This source has been used in other studies, such as Tan and Mahoney (2006); Gaur, Delios, and Singh (2007); Wilkinson, Peng, Brouthers, and Beamish (2008). But these studies did not make use of all relevant firm-specific variables in the source, nor of multi-year panel data.

${ }^{3}$ The comparative study was limited to Asian countries for two reasons. These countries comprise a wide range of risk indicators, while such indicators vary less across European and North American countries. In 2004, 49\% of Japanese subsidiaries were located in Asia, compared to $14 \%$ in Europe, $31 \%$ in Canada, USA and Mexico and 6\% elsewhere, while subsidiaries in Asian countries were across a greater range of e.g. size and industries than in the rest of the world.

${ }^{4}$ Ideally, capital should be the total assets or total equity (paid-up capital plus retained earnings) of a subsidiary company. The database only gives paid-up capital, valued at the year in which the most recent addition was made to the equity of the subsidiary, generally the year of establishment (Beamish, Delios, and Lecraw 1997, 108). Consequently, the actual value of invested capital of older subsidiary ventures is underestimated, because of inflation since establishment and/or currency depreciation relative to the US\$, and/or an accumulation of re-invested earnings. For that reason, paid-up capital data are converted for this paper to US\$ in constant 2000 prices, calculated firstly by using the exchange rate (local currency unit per US\$) in the year of establishment, and secondly by correcting for inflation with the Gross Fixed Capital Formation deflator (in US\$, $2000=100$ ) from the national accounts of the United States. Other studies, such as Gaur, Delios, and Singh (2007) also used capital as a control variable, but omitted this important correction.
} 
purpose of funding the expansion of their operations in other countries, such as China and more recently in India. ${ }^{5}$

Across host countries, MNCs face different levels of risk. Several indicators of country risk are readily available for the purpose of analysing the impact of perceived risk on expatriation and these have been used in multi-country studies, as mentioned above. Another example is the OECD's classification of country risk. As noted, there are several problems with these indicators. For example, the OECD's classification is explicitly intended for export insurance agencies and reflects the perceived risk to international payments. It is based on the payment experiences of OECD countries with partner countries, as well as indicators of the financial and economic situation in these countries. Other composite indicators are based on publicly available financial and economic data, aggregated with arbitrary weightings. Hence, the choice of country risk indicator therefore impacts on the results. To avoid the possible complications caused by the choice of a highly aggregated composite indicator this paper we use indicators that capture factors relevant to FDI decisions, obtained from the World Bank's Governance and Doing Business databases. ${ }^{6}$

The Governance indicators are measured in units, with higher values corresponding to better governance outcomes. Unlike the Governance indicators, the Doing Business variables are not available for each year of our database. For estimation purposes, these Doing Business variables are therefore regarded as constant for 1999-2004. We use the following indicators:

World Bank Governance variables:

- political stability and absence of violence;

- regulatory quality;

- rule of law;

- control of corruption;

World Bank Doing Business variables:

- number of procedures necessary to enforcing contracts;

- number of procedures necessary to start a business.

The level of competitive risk that firms face varies across manufacturing industries. Steel producers face different competitive challenges than textile and garment producers. The Tōyō Keizai database identifies 18 manufacturing industries: food processing; textiles; wood \& furniture; pulp \& paper; publishing \& printing; chemicals \& medicines; petrochemical; rubber, leather \& plastics; ceramics, stone \& glass; steel; nonferrous metals; nonferrous metal products; machinery; electrical \& electronic equipment; automotive \& parts; precision tools; transport machinery \& shipbuilding; other manufacturing. Industry-level indicators of competitive risk across industries are unavailable; we

\footnotetext{
${ }^{5}$ For instance, in Thailand, Toshiba Semiconductors Thailand Co Ltd is a joint venture established in 1990 by Toshiba (Japan, holding 32.9\% of the shares), Toshiba Electronics Malaysia Sdn Bhd (incorporated in Malaysia 45.6\%) and Toshiba Electric Asia Pte Ltd (incorporated in Singapore 19\%), along with a local investor (2.5\%). Another example is Hitachi Chemical Shanghai in China, a wholly owned subsidiary established in 1998 by Hitachi Chemical Co Ltd, which is a JV incorporated in Hong Kong and controlled by Japanese parent company Hitachi Chemical (Japan, $88.6 \%$ ) and Taiwan Hitachi Chemical (Taiwan, 11.4\%).

${ }^{6} \mathrm{See}$. http://www.worldbank.org/wbi/governance/data and http://www.doingbusiness.org
} 
include industry dummy variables in our regressions in an attempt to capture the competitive risk factors in these different industries. ${ }^{7}$

The descriptive statistics in Table 1 show that $25 \%$ of the firms in the sample are located in China, almost $16 \%$ in Thailand, $11 \%$ in Hong Kong, $10 \%$ in Taiwan, $9 \%$ in Malaysia, and $7 \%$ in Indonesia. On average, firms in China, Vietnam and India are younger than their counterparts in other countries, reflecting the fact that these countries opened up to FDI later than others. In terms of size, the subsidiaries on average have about 300 to 500 employees. In South Korea, Hong Kong, Singapore and Taiwan firms have fewer employees on average, which is most likely a reflection of the higher degree of skill- and technology intensity in the production activities in those countries.

The average share of Japanese expatriate employment is $7.4 \%$, which is higher than the averages in several countries, such as $3.4 \%$ in Indonesia. The share is relatively high in Hong Kong (23.4\%) and Singapore $(20.8 \%)$, which may reflect the fact that many firms in those countries are relatively small operations with their main manufacturing activities located in China in the case of Hong Kong, or elsewhere in Southeast Asia in the case of Singapore. The ratio of capital and employment indicates that capital intensity of production is significantly higher in Hong Kong, Singapore and Taiwan than in other countries. This suggests the use of more advanced and more capital-intensive production technologies. The share of Japanese partners in the subsidiary firms was on average $93 \%$ in Hong Kong and Singapore, compared to $77 \%$ in Taiwan, which indicates that most firms are majority-owned by Japanese parent firms.

\begin{tabular}{|c|c|c|c|c|c|c|c|c|c|c|c|c|c|}
\hline Variables & China & Indonesia & $\begin{array}{c}\begin{array}{c}\text { Philip- } \\
\text { pines }\end{array} \\
\end{array}$ & Thailand & Vietnam & Malaysia & $\begin{array}{l}\text { South } \\
\text { Korea }\end{array}$ & $\begin{array}{l}\text { Hong } \\
\text { Kong } \\
\end{array}$ & Singapore & Taiwan & India & Pakistan & $\begin{array}{c}\text { Sri } \\
\text { Lanka }\end{array}$ \\
\hline Number of firms & 1,421 & 395 & 253 & 886 & 103 & 515 & 213 & 603 & 690 & 541 & 66 & 6 & 11 \\
\hline Av. total employment & $\begin{array}{c}306 \\
(848)\end{array}$ & $\begin{array}{c}443 \\
(682)\end{array}$ & $\begin{array}{c}454 \\
(1,345)\end{array}$ & $\begin{array}{c}312 \\
(743)\end{array}$ & $\begin{array}{l}283 \\
(678)\end{array}$ & $\begin{array}{c}322 \\
(683)\end{array}$ & $\begin{array}{c}222 \\
(559)\end{array}$ & $\begin{array}{c}116 \\
(562)\end{array}$ & $\begin{array}{c}85 \\
(252)\end{array}$ & $\begin{array}{l}171 \\
(375)\end{array}$ & $\begin{array}{c}531 \\
(1,053)\end{array}$ & $\begin{array}{c}461 \\
(450)\end{array}$ & $\begin{array}{c}1,400 \\
(2,546)\end{array}$ \\
\hline $\begin{array}{l}\text { Av. Japanese expatriate } \\
\text { employment }\end{array}$ & $\begin{array}{c}4 \\
(8)\end{array}$ & $\begin{array}{l}4 \\
(4)\end{array}$ & $\begin{array}{l}4 \\
(5)\end{array}$ & $\begin{array}{l}4 \\
(5)\end{array}$ & $\begin{array}{l}3 \\
(3)\end{array}$ & $\begin{array}{c}4 \\
(5)\end{array}$ & $\begin{array}{l}2 \\
(3)\end{array}$ & $\begin{array}{l}4 \\
(5)\end{array}$ & $\begin{array}{l}4 \\
(7)\end{array}$ & $\begin{array}{l}3 \\
(4)\end{array}$ & $\begin{array}{l}3 \\
(4)\end{array}$ & $\begin{array}{l}3 \\
(3)\end{array}$ & $\begin{array}{l}4 \\
(4)\end{array}$ \\
\hline $\begin{array}{l}\text { Av. ratio of Japanese } \\
\text { expatriates and } \\
\text { employment }\end{array}$ & $\begin{array}{c}0.054 \\
(0.095)\end{array}$ & $\begin{array}{l}0.0345 \\
(0.056)\end{array}$ & $\begin{array}{c}0.053 \\
(0.081)\end{array}$ & $\begin{array}{c}0.067 \\
(0.107)\end{array}$ & $\begin{array}{c}0.046 \\
(0.078)\end{array}$ & $\begin{array}{c}0.075 \\
(0.119)\end{array}$ & $\begin{array}{c}0.091 \\
(0.141)\end{array}$ & $\begin{array}{c}0.234 \\
(0.204)\end{array}$ & $\begin{array}{c}0.208 \\
(0.198)\end{array}$ & $\begin{array}{c}0.105 \\
(0.140)\end{array}$ & $\begin{array}{c}0.043 \\
(0.079)\end{array}$ & $\begin{array}{c}0.008 \\
(0.004)\end{array}$ & $\begin{array}{c}0.049 \\
(0.123)\end{array}$ \\
\hline $\begin{array}{l}\text { Av. paid-up capital } \\
\text { (1,000 US\$, } 2000 \\
\text { prices) }\end{array}$ & $\begin{array}{c}8,861 \\
(25,497)\end{array}$ & $\begin{array}{c}9,482 \\
(50,662)\end{array}$ & $\begin{array}{c}4,713 \\
(9,515)\end{array}$ & $\begin{array}{c}5,354 \\
(22,989)\end{array}$ & $\begin{array}{c}4,662 \\
(5,495)\end{array}$ & $\begin{array}{c}5,947 \\
(19,200)\end{array}$ & $\begin{array}{c}9,349 \\
(38,495)\end{array}$ & $\begin{array}{c}4,225 \\
(13,815)\end{array}$ & $\begin{array}{c}10,205 \\
(312,070)\end{array}$ & $\begin{array}{c}8,852 \\
(34,471)\end{array}$ & $\begin{array}{c}7,245 \\
(18,686)\end{array}$ & $\begin{array}{c}3,987 \\
(3,888)\end{array}$ & $\begin{array}{c}23,379 \\
(64,496)\end{array}$ \\
\hline $\begin{array}{l}\text { Av. capital per } \\
\text { employee ( } 1,000 \text { US\$, } \\
2000 \text { prices) }\end{array}$ & $\begin{array}{c}124 \\
(1,589)\end{array}$ & $\begin{array}{c}45 \\
(203)\end{array}$ & $\begin{array}{c}37 \\
(101)\end{array}$ & $\begin{array}{c}43 \\
(263)\end{array}$ & $\begin{array}{c}59 \\
(100)\end{array}$ & $\begin{array}{c}40 \\
(188)\end{array}$ & $\begin{array}{c}58 \\
(72)\end{array}$ & $\begin{array}{c}224 \\
(811)\end{array}$ & $\begin{array}{c}243 \\
(1,293)\end{array}$ & $\begin{array}{c}229 \\
(4,804)\end{array}$ & $\begin{array}{l}38 \\
(81)\end{array}$ & $\begin{array}{c}13 \\
(18)\end{array}$ & $\begin{array}{c}67 \\
(255)\end{array}$ \\
\hline $\begin{array}{l}\text { Av. number of } \\
\text { Japanese joint venture } \\
\text { partners }\end{array}$ & $\begin{array}{c}1.5 \\
(0.8)\end{array}$ & $\begin{array}{c}1.6 \\
(0.8)\end{array}$ & $\begin{array}{c}1.4 \\
(0.7)\end{array}$ & $\begin{array}{c}2.2 \\
(1.9)\end{array}$ & $\begin{array}{c}1.6 \\
(0.8)\end{array}$ & $\begin{array}{c}1.3 \\
(0.7)\end{array}$ & $\begin{array}{c}1.2 \\
(0.4)\end{array}$ & $\begin{array}{c}1.2 \\
(0.5)\end{array}$ & $\begin{array}{c}1.2 \\
(0.5)\end{array}$ & $\begin{array}{c}1.2 \\
(0.6)\end{array}$ & $\begin{array}{c}1.5 \\
(0.7)\end{array}$ & $\begin{array}{c}1.4 \\
(0.5)\end{array}$ & $\begin{array}{l}1.3 \\
(0.6)\end{array}$ \\
\hline $\begin{array}{l}\text { Av. capital share of all } \\
\text { Japanese partners }\end{array}$ & $\begin{array}{c}0.715 \\
(0.250)\end{array}$ & $\begin{array}{c}0.703 \\
(0.254)\end{array}$ & $\begin{array}{c}0.766 \\
(0.282)\end{array}$ & $\begin{array}{c}0.608 \\
(0.255)\end{array}$ & $\begin{array}{c}0.770 \\
(0.241)\end{array}$ & $\begin{array}{c}0.733 \\
(0.299)\end{array}$ & $\begin{array}{c}0.718 \\
(0.269)\end{array}$ & $\begin{array}{c}0.931 \\
(0.173)\end{array}$ & $\begin{array}{c}0.930 \\
(0.168)\end{array}$ & $\begin{array}{c}0.756 \\
(0.257)\end{array}$ & $\begin{array}{c}0.563 \\
(0.269)\end{array}$ & $\begin{array}{c}0.509 \\
(0.297)\end{array}$ & $\begin{array}{c}0.848 \\
(0.269)\end{array}$ \\
\hline $\begin{array}{l}\text { Av. capital share of } \\
\text { local partners }\end{array}$ & $\begin{array}{c}0.231 \\
(0.238)\end{array}$ & $\begin{array}{c}0.228 \\
(0.224)\end{array}$ & $\begin{array}{c}0.193 \\
(0.267)\end{array}$ & $\begin{array}{c}0.245 \\
(0.247)\end{array}$ & $\begin{array}{c}0.188 \\
(0.214)\end{array}$ & $\begin{array}{c}0.194 \\
(0.275)\end{array}$ & $\begin{array}{c}0.257 \\
(0.269)\end{array}$ & $\begin{array}{c}0.042 \\
(0.137)\end{array}$ & $\begin{array}{c}0.040 \\
(0.127)\end{array}$ & $\begin{array}{c}0.208 \\
(0.248)\end{array}$ & $\begin{array}{c}0.390 \\
(0.265)\end{array}$ & $\begin{array}{c}0.440 \\
(0.324)\end{array}$ & $\begin{array}{c}0.095 \\
(0.231)\end{array}$ \\
\hline Av. age (years) & $\begin{array}{c}6.8 \\
(3.1)\end{array}$ & $\begin{array}{l}11.7 \\
(8.6)\end{array}$ & $\begin{array}{c}9.5 \\
(7.2)\end{array}$ & $\begin{array}{l}12.5 \\
(9.0)\end{array}$ & $\begin{array}{c}5.2 \\
(2.1)\end{array}$ & $\begin{array}{l}11.7 \\
(6.9)\end{array}$ & $\begin{array}{l}12.0 \\
(8.6)\end{array}$ & $\begin{array}{l}14.6 \\
(9.3)\end{array}$ & $\begin{array}{l}14.4 \\
(8.1)\end{array}$ & $\begin{array}{l}14.8 \\
(9.8)\end{array}$ & $\begin{array}{l}7.7 \\
(6.5)\end{array}$ & $\begin{array}{l}16.9 \\
(6.4)\end{array}$ & $\begin{array}{l}13.6 \\
(10.0)\end{array}$ \\
\hline
\end{tabular}

For the analysis in the next section, we take the logarithms of some key variables and assume a nonlinear relationship between the explanatory and dependent variables. Table 2 shows the pair-wise correlations. Capital intensity is defined as the ratio of capital and total employment. Except for the correlation between the share of Japanese parent firms and the share of the local partner firms in the capital of companies, the correlations between the explanatory variables are all low, which indicates an absence of multicollinearity problems.

\footnotetext{
${ }^{7}$ In principle, the use of industry dummy variables identifies the difference between market-seeking firms focused on sales in the host country and requiring greater knowledge of the local market, and resource-seeking firms focused on exports.
} 
The difference between the share of Japanese parent firms and the share of the local partner firms in the capital of companies is that in several cases third-country investment plays a role, as explained above.

Table 2: Pair-Wise Correlations

\begin{tabular}{lrrrrrrrr}
\hline & Mean & St.Dev. & 1 & 2 & 3 & 4 & 5 & 6 \\
\hline 1. Share of expatriates & 0.100 & 0.150 & 1.000 & & & & & \\
2. Capital intensity & 125 & 1,772 & 0.095 & 1.000 & & & & \\
3. Number of Japanese JV & 1.5 & 1.0 & -0.140 & -0.019 & 1.000 & & & \\
partners & & & & & & & & \\
$\begin{array}{l}\text { 4. Share of Japanese JV } \\
\text { partners }\end{array}$ & 0.754 & 0.266 & 0.280 & 0.034 & -0.195 & 1.000 & & \\
5. Age & 11.3 & 8.1 & -0.098 & -0.026 & -0.045 & -0.036 & 1.000 & \\
6. Share local JV partners & 0.184 & 0.241 & -0.272 & -0.029 & 0.043 & -0.828 & 0.048 & 1.000 \\
\hline
\end{tabular}

The underlying equation used to investigate the determinants of the share of expatriate employment implies that total employment is on both sides of the equation because we hypothesise that capital intensity is a key explanatory variable. The justification is we are not seeking to explain the engagement of the absolute number of expatriates on the basis of specified explanatory variables. The specification we use is required because a number of variables identified as potentially explanatory are not expressed as a ratio to total employment, in particular the share of Japanese or local investors in social capital. In addition, a risk of endogeneity exists if we have both social capital and total employment as explanatory variables and the absolute number of expatriates as dependent variable.

\section{Data Analysis}

To analyse the data and test the validity of the hypotheses, we use multiple regression techniques (OLS and Random effects). The OLS results are shown in Table 3. As the Doing Business variables are constant for all years in the dataset, we checked the robustness of the fixed effect results by estimating the random effects, which are shown in Table 4. Both tables show very similar results. In all models, $\mathrm{R}^{2}$ and the explanatory power of the models are high. Capital intensity has a positive sign and is statistically significant as an explanatory variable for the degree of expatriation, which confirms Hypothesis 1. The share of foreign parent firms in the capital of the capital of the subsidiary was statistically significant and has a positive sign in model (1), while the share of all local partners used in models (2) - (8) has a negative sign and is also statistically significant

This confirms Hypothesis 2 and suggests that MNCs skew the human resource policies of their foreign subsidiary firms towards employing home country expatriates, most likely in key management positions. In all cases the age of the subsidiary firm moderates expatriation, because the sign of was negative and the coefficient is statistically significant, thus confirming Hypothesis 3 . Hence, subsidiary firms that have been in operation longer are more likely to engage locals in senior management positions. 
Table 3: Estimation Results (OLS)

\begin{tabular}{|c|c|c|c|c|c|c|c|c|}
\hline \multirow[b]{2}{*}{ Variables: } & \multicolumn{8}{|c|}{ Dependent variable: Share of expatriates } \\
\hline & $(1)$ & (2) & (3) & (4) & (5) & $(6)$ & (7) & $(8)$ \\
\hline Capital intensity & $\begin{array}{l}0.292 * * \\
(0.006)\end{array}$ & $\begin{array}{l}0.295 * * \\
(0.005)\end{array}$ & $\begin{array}{l}0.254 * * \\
(0.005)\end{array}$ & $\begin{array}{l}0.244 * * \\
(0.005)\end{array}$ & $\begin{array}{l}0.246 * * \\
(0.005)\end{array}$ & $\begin{array}{l}0.242 * * \\
(0.005)\end{array}$ & $\begin{array}{l}0.242 * * \\
(0.005)\end{array}$ & $\begin{array}{l}0.249 * * \\
(0.005)\end{array}$ \\
\hline Number of Japanese corporations & $\begin{array}{l}-0.007 \\
(0.006)\end{array}$ & & & & & & & \\
\hline Share of total Japanese investment in the & $\begin{array}{l}0.423 * * \\
(0.018)\end{array}$ & & & & & & & \\
\hline Age & $\begin{array}{l}- \\
(0.011)\end{array}$ & $\begin{array}{l}- \\
(0.010)\end{array}$ & $\begin{array}{l}- \\
(0.010)\end{array}$ & $\begin{array}{l}- \\
(0.011)\end{array}$ & $\begin{array}{l}- \\
(0.011)\end{array}$ & $\begin{array}{l}- \\
(0.011)\end{array}$ & $\begin{array}{l}- \\
(0.012)\end{array}$ & $\begin{array}{l}- \\
(0.012)\end{array}$ \\
\hline Share of all local partners in the subsidiary & & $\begin{array}{l}- \\
(0.030)\end{array}$ & $\begin{array}{l}- \\
(0.030)\end{array}$ & $\begin{array}{l}- \\
(0.031)\end{array}$ & $(0.030)$ & $\begin{array}{l}- \\
(0.031)\end{array}$ & (0.033) & $\begin{array}{l}- \\
(0.033)\end{array}$ \\
\hline Political stability and absence of & & & $\begin{array}{l}0.332 * * \\
(0.010)\end{array}$ & & & & & \\
\hline Regulatory quality & & & & $\begin{array}{l}0.455 * * \\
(0.010)\end{array}$ & & & & \\
\hline Rule of law & & & & & $\begin{array}{l}0.451 * * \\
(0.010)\end{array}$ & & & \\
\hline Control of corruption & & & & & & $\begin{array}{l}0.330 * * \\
(0.008)\end{array}$ & $\begin{array}{l}0.210 * * \\
(0.030)\end{array}$ & $\begin{array}{l}0.168 * * \\
(0.010)\end{array}$ \\
\hline Enforcing contracts & & & & & & & $\begin{array}{l}- \\
(0.149)\end{array}$ & \\
\hline Starting a business & & & & & & & & $\begin{array}{l}- \\
(0.032)\end{array}$ \\
\hline Constant & $\begin{array}{l}- \\
(0.035)\end{array}$ & $\begin{array}{l}- \\
(0.032)\end{array}$ & $\begin{array}{l}- \\
(0.034)\end{array}$ & $\begin{array}{l}- \\
(0.034)\end{array}$ & $\begin{array}{l}- \\
(0.035)\end{array}$ & $\begin{array}{l}- \\
(0.032)\end{array}$ & $\begin{array}{l}-0.071 \\
(0.520)\end{array}$ & $\begin{array}{l}- \\
(0.108)\end{array}$ \\
\hline $\mathrm{N}$ & 24,676 & 24,676 & 24,676 & 24,676 & 24,676 & 24,676 & 20,260 & 20,260 \\
\hline R-squared & 0.59 & 0.61 & 0.60 & 0.60 & 0.59 & 0.61 & 0.62 & 0.63 \\
\hline
\end{tabular}

Notes: The following variables are expressed as logarithms in all regression models: share of expatriates, capital intensity, share of total Japanese investment in the subsidiary and age. The estimation of each model includes dummy variables for each industry and each year of observation. Robust standard errors are in parenthesis.

As for the indicators of country risk, in models (3) - (6) the Governance variables all have a positive sign and are statistically significant. This implies that a higher degree of political stability, regulatory quality, rule of law, and control of corruption is associated with a higher the degree of expatriation. Conversely, in countries with a more risky business environment, subsidiary companies are likely to depend to a greater degree on locally recruited senior staff members. Likewise, in models (7) and (8), the two Doing Business indicators have a negative sign and are statistically significant. This means that increased difficulties experienced in establishing a subsidiary venture, or higher risk, reduces reliance on expatriates, and by implication increases reliance on local senior staff. In both these models we included the 'control of corruption' indicator to test for interaction with the 'enforcing contracts' and 'starting a business' procedures. The results are statistically significant. In the case of a country with more procedures to enforce contracts, better control of corruption enhances reliance on local senior staff. In the case of a country with more procedures to start a business, better control of corruption enhances reliance on expatriates. In all cases, Hypothesis (4) is confirmed: higher perceived country risk relevant to FDI-related decisions leads a firm to localise senior management. 
Table 4: Estimation Results (Random Effects)

\begin{tabular}{|c|c|c|c|c|c|c|c|c|}
\hline \multirow[b]{2}{*}{ Variables: } & \multicolumn{8}{|c|}{ Dependent variable: Share of expatriates } \\
\hline & $(1)$ & $(2)$ & $(3)$ & $(4)$ & $(5)$ & $(6)$ & $(7)$ & $(8)$ \\
\hline Capital intensity & $\begin{array}{l}0.411 * * \\
(0.008)\end{array}$ & $\begin{array}{l}{ }^{*} 0.404^{*} \\
(0.008)\end{array}$ & $\begin{array}{c}0.389^{* * *} \\
(0.008)\end{array}$ & $\begin{array}{l}0.374 * * \\
(0.008)\end{array}$ & $\begin{array}{l}0.377 * * \\
(0.008)\end{array}$ & $\begin{array}{l}0.373 * * \\
(0.008)\end{array}$ & $\begin{array}{l}0.371 * * \\
(0.008)\end{array}$ & $\begin{array}{l}0.376^{* *} \\
(0.008)\end{array}$ \\
\hline Number of Japanese corporations & $\begin{array}{l}-0.005 \\
(0.005)\end{array}$ & & & & & & & \\
\hline Share of total Japanese investment in the & $\begin{array}{l}0.151 * * \\
(0.024)\end{array}$ & & & & & & & \\
\hline Age & $\begin{array}{l}- \\
(0.013)\end{array}$ & $\begin{array}{l}- \\
(0.012)\end{array}$ & $\begin{array}{l}- \\
(0.012)\end{array}$ & $\begin{array}{l}- \\
(0.013)\end{array}$ & $\begin{array}{l}- \\
(0.012)\end{array}$ & $\begin{array}{l}- \\
(0.012)\end{array}$ & $\begin{array}{l}- \\
(0.014)\end{array}$ & $\begin{array}{l}- \\
(0.014)\end{array}$ \\
\hline Share of all local partners in the subsidiary & & $\begin{array}{l}- \\
(0.034)\end{array}$ & $\begin{array}{l}- \\
(0.034)\end{array}$ & $\begin{array}{l}- \\
(0.034)\end{array}$ & $\begin{array}{l}- \\
(0.034)\end{array}$ & $\begin{array}{l}- \\
(0.034)\end{array}$ & $\begin{array}{l}- \\
(0.038)\end{array}$ & $\begin{array}{l}- \\
(0.037)\end{array}$ \\
\hline Political stability and absence of & & & $\begin{array}{l}0.174 * * \\
(0.012)\end{array}$ & & & & & \\
\hline Regulatory quality & & & & $\begin{array}{l}0.422 * * \\
(0.014)\end{array}$ & & & & \\
\hline Rule of law & & & & & $\begin{array}{l}0.282 * * \\
(0.014)\end{array}$ & & & \\
\hline Control of corruption & & & & & & $\begin{array}{l}0.293 * * \\
(0.012)\end{array}$ & $\begin{array}{l}- \\
(0.025)\end{array}$ & $\begin{array}{l}0.066 * * \\
(0.017)\end{array}$ \\
\hline Enforcing contracts & & & & & & & $\begin{array}{l}- \\
(0.144)\end{array}$ & \\
\hline Starting a business & & & & & & & & $\begin{array}{l}- \\
(0.061)\end{array}$ \\
\hline Constant & $\begin{array}{l}- \\
(0.226)\end{array}$ & $\begin{array}{l}- \\
(0.223)\end{array}$ & $\begin{array}{l}- \\
(0.198)\end{array}$ & $\begin{array}{l}- \\
(0.250)\end{array}$ & $\begin{array}{l}- \\
(0.247)\end{array}$ & $\begin{array}{l}- \\
(0.240)\end{array}$ & $\begin{array}{l}4.609 * * \\
(0.537)\end{array}$ & $\begin{array}{l}- \\
(0.247)\end{array}$ \\
\hline $\mathrm{N}$ & 22,634 & 24,676 & 24,676 & 24,676 & 24,676 & 24,676 & 20,260 & 20,260 \\
\hline R-squared & 0.45 & 0.45 & 0.48 & 0.53 & 0.51 & 0.51 & 0.53 & 0.55 \\
\hline
\end{tabular}

Notes: The following variables are expressed as logarithms in all regression models: share of expatriates, capital intensity, share of total Japanese investment in the subsidiary and age. The estimation of each model includes dummy variables for each industry and each year of observation. Robust standard errors are in parenthesis.

Tables 5 and 6 show the results of further OLS and random effects analyses in order to distinguish between some firm-specific characteristics. The results in the table test whether there is any difference in expatriation strategies between different types of firms in the dataset. The reason for this additional analysis is that there could be country-specific differences between subsidiary firms that are not captured and revealed in Tables 3 and 4 . These differences are in this case analysed only with the Governance indicator 'control of corruption' interacting with the two Doing Business indicators.

The first distinction is between firms that produce with advanced technologies and a high capital intensity of production and those that produce with simple technologies and a low capital intensity. The first may be more exposed to risk than the latter and more concentrated in one country than another, because there are differences in the average capital intensity shown in Table 1. It is significantly higher in Hong Kong, Singapore and Taiwan than elsewhere. However, models (1) - (4) in Table 6 show that the signs are all the same as in model (7) in Table 4, and significant, although the values of the coefficients are different, particularly for the 'share of all local partners' variable. 


\begin{tabular}{|c|c|c|c|c|c|c|c|c|c|c|c|c|}
\hline \multirow{3}{*}{ Variables: } & \multicolumn{12}{|c|}{ Dependent variable: Share of expatriates } \\
\hline & \multicolumn{2}{|c|}{$\begin{array}{l}\text { High capital } \\
\text { Intensity }\end{array}$} & \multicolumn{2}{|c|}{$\begin{array}{l}\text { Low capital } \\
\text { intensity }\end{array}$} & \multicolumn{2}{|c|}{$\begin{array}{c}\text { Large } \\
\text { subsidiaries }\end{array}$} & \multicolumn{2}{|c|}{$\begin{array}{c}\text { Small } \\
\text { subsidiaries }\end{array}$} & \multicolumn{2}{|c|}{ Excluding China } & \multicolumn{2}{|c|}{$\begin{array}{c}\text { Excluding Hong Kong } \\
\text { and Singapore }\end{array}$} \\
\hline & (1) & (2) & (3) & (4) & (5) & (6) & (7) & (8) & (9) & $(10)$ & (11) & (12) \\
\hline \multirow[t]{2}{*}{ Capital intensity } & $0.207^{* * *}$ & $0.204 * * *$ & $0.208^{* * *}$ & $0.212 * * *$ & $0.225^{* * *}$ & $0.221^{* * *}$ & $0.111^{* * *}$ & $0.110^{* * *}$ & $0.225^{* * *}$ & $0.220^{* * *}$ & $0.225^{* * *}$ & $0.266^{* * *}$ \\
\hline & $(0.006)$ & $(0.006)$ & $(0.011)$ & $(0.011)$ & $(0.006)$ & $(0.006)$ & $(0.004)$ & $(0.004)$ & $(0.006)$ & $(0.006)$ & $(0.006)$ & $(0.007)$ \\
\hline \multirow[t]{2}{*}{ Age } & $-0.315^{* * *}$ & $-0.322 * * *$ & $-0.282 * * *$ & $-0.294^{* * *}$ & $-0.079^{* * *}$ & $-0.094 * * *$ & $-0.191 * * *$ & $-0.194 * * *$ & $-0.339^{* * *}$ & $-0.364^{* * *}$ & $-0.339 * * *$ & $-0.363^{* * *}$ \\
\hline & $(0.010)$ & $(0.010)$ & $(0.016)$ & $(0.016)$ & $(0.012)$ & $(0.012)$ & $(0.009)$ & $(0.009)$ & $(0.013)$ & $(0.014)$ & $(0.013)$ & $(0.015)$ \\
\hline \multirow[t]{2}{*}{ Share of all local partners in the subsidiary } & $-1.197^{* * *}$ & $-1.198^{* * *}$ & $-0.482 * * *$ & $-0.481 * * *$ & $-0.749^{* * *}$ & $-0.754 * * *$ & $-0.914 * * *$ & $-0.912 * * *$ & $-0.570^{* * *}$ & $-0.584 * * *$ & $-0.570 * * *$ & $-0.556^{* * *}$ \\
\hline & $(0.039)$ & $(0.039)$ & $(0.047)$ & $(0.047)$ & $(0.033)$ & $(0.033)$ & $(0.039)$ & $(0.039)$ & $(0.042)$ & $(0.041)$ & $(0.042)$ & $(0.034)$ \\
\hline \multirow[t]{2}{*}{ Control of corruption } & $0.221^{* * *}$ & $0.252^{* * *}$ & $0.333^{* * *}$ & $0.287^{* * *}$ & $0.101^{* * *}$ & $0.111^{* * *}$ & $0.206^{* * *}$ & $0.208^{* * *}$ & $0.113^{* * *}$ & $0.204^{* * *}$ & $0.113^{* * *}$ & $0.141^{* * *}$ \\
\hline & $(0.009)$ & $(0.010)$ & $(0.016)$ & $(0.015)$ & $(0.010)$ & $(0.012)$ & $(0.009)$ & $(0.009)$ & $(0.032)$ & $(0.011)$ & $(0.032)$ & $(0.024)$ \\
\hline \multirow[t]{2}{*}{ Enforcing contracts } & $-0.220^{* * *}$ & & $-0.124 *$ & & $-0.400^{* * *}$ & & $-0.057^{*}$ & & $-1.043^{* * *}$ & & $-1.043^{* * *}$ & \\
\hline & $(0.037)$ & & $(0.070)$ & & $(0.052)$ & & $(0.033)$ & & $(0.160)$ & & $(0.160)$ & \\
\hline \multirow[t]{2}{*}{ Starting a business } & & 0.021 & & $-0.241 * * *$ & & $-0.103 * * *$ & & -0.026 & & $-0.664^{* * *}$ & & $-0.734^{* * *}$ \\
\hline & & $(0.024)$ & & $(0.035)$ & & $(0.028)$ & & $(0.022)$ & & $(0.037)$ & & $(0.041)$ \\
\hline \multirow[t]{2}{*}{ Constant } & $-2.101^{* * *}$ & $-2.930^{* * *}$ & -0.010 & $-1.189^{* * *}$ & $-1.464^{* * *}$ & $-3.599 * * *$ & $-0.873^{* * *}$ & $-1.010^{* * *}$ & $2.246^{* * *}$ & $-0.714^{* * *}$ & $-1.715^{* * *}$ & $-0.859^{* * *}$ \\
\hline & $(0.148)$ & $(0.088)$ & $(0.284)$ & $(0.086)$ & $(0.184)$ & $(0.071)$ & $(0.113)$ & $(0.055)$ & $(0.546)$ & $(0.126)$ & $(0.616)$ & $(0.097)$ \\
\hline $\mathrm{N}$ & 23,234 & 23,234 & 11,419 & 11,419 & 16,427 & 16,427 & 18,226 & 18,226 & 14,640 & 14,640 & 15,203 & 15,203 \\
\hline R-squared & 0.53 & 0.53 & 0.57 & 0.58 & 0.43 & 0.43 & 0.37 & 0.37 & 0.63 & 0.63 & 0.53 & 0.54 \\
\hline
\end{tabular}

Notes: The following variables are expressed as logarithms in all regression models: share of expatriates, capital intensity, share of total Japanese investment in the subsidiary and age. The estimation of each model includes dummy variables for each industry and each year of observation. Robust standard errors are in parenthesis. * significant at $10 \%$; ** significant at $5 \%$; ${ }^{* *}$ significant at $1 \%$

In capital intensive firms, a higher share of local partners decreases the rate of expatriation more than in capital extensive firms. This indicates that local partners in a capital intensive firm are in a better position to require the appointment of local staff members, because of their ownership rights. While in capital extensive firms local partners are less likely to use their ownership rights to require the appointment of local staff members.

Secondly, Tables 5 and 6 distinguish between large and small subsidiaries in terms of the numbers of people employed. Table 1 showed that average total employment is relatively high in Indonesia, Philippines, India and Pakistan, as well as Sri Lanka, and on average relatively small in Hong Kong and Singapore. Models (5) - (8) in Table 6 show that the signs are all the same as in model (7) in Table 4, and significant, although the values of the coefficients are different, particularly for capital intensity. This indicates that large subsidiary firms that are capital intensive on average employ a greater proportion of expatriates than small subsidiaries that are capital extensive. 


\begin{tabular}{|c|c|c|c|c|c|c|c|c|c|c|c|c|}
\hline \multirow{3}{*}{ Variables: } & \multicolumn{12}{|c|}{ Dependent variable: Stafe of expacriates } \\
\hline & \multicolumn{2}{|c|}{$\begin{array}{l}\text { High eapital } \\
\text { imsensity }\end{array}$} & \multicolumn{2}{|c|}{$\begin{array}{l}\text { Low capital } \\
\text { intensity }\end{array}$} & \multicolumn{2}{|c|}{$\begin{array}{c}\text { Large } \\
\text { subsidiaries }\end{array}$} & \multicolumn{2}{|c|}{$\begin{array}{c}\text { Small } \\
\text { subsidiaries }\end{array}$} & \multicolumn{2}{|c|}{ Excluding China } & \multicolumn{2}{|c|}{$\begin{array}{l}\text { Exeluding Hong Kang } \\
\text { and Singapore }\end{array}$} \\
\hline & (1) & (2) & (3) & (4) & (5) & (6) & (7) & (8) & (9) & (10) & (11) & (12) \\
\hline \multirow[t]{2}{*}{ Capital intensity } & $0.343 \cdots$ & $\bullet 0.340 * *$ & $\bullet 0.387 \cdots$ & $0.389 * \cdots$ & $\cdot 0.360^{t * *}$ & $0.358 \cdots$ & $0.219 * \cdots$ & $0.217 *$ & $0.342 \cdots$ & $0.340 * *$ & $0.401 \cdots$ & $0.407 * \cdots$ \\
\hline & $(0.009)$ & $(0.009)$ & $(0.014)$ & $(0.014)$ & $(0.009)$ & $(0.009)$ & $(0.007)$ & $(0.007)$ & $(0.010)$ & (0.010) & $(0.010)$ & $(0.010)$ \\
\hline \multirow[t]{2}{*}{ Age } & $0.165 * \cdots$ & $\cdot 0.172 * \cdots$ & $+0.106 *$ & $0.128 * \cdots$ & $-0096 \cdots$ & $0.108 \cdots$ & $-0.120 * \cdots$ & $0.125 *$ & $-0.213 \cdots$ & $-0.216 * *+$ & $-0.189 * \cdots$ & $-0.217 * \cdots$ \\
\hline & $(0.012)$ & $(0.012)$ & $(0.021)$ & $(0.021)$ & $(0.017)$ & $(0.017)$ & $(0.011)$ & $(0.011)$ & $(0.017)$ & (0017) & $(0.017)$ & $(0.017)$ \\
\hline \multirow[t]{2}{*}{ Stare of all local partsers in the subsidiary } & $0.564 \cdots$ & • & $\cdot \dot{0} \cdot 106 \cdots$ & $0,161 \cdots$ & $-0.374 \cdots$ & $0.378 \cdots$ & $-0.385 * *+$ & $0.381 *$ & $-0.170 * \cdots$ & $-0.205 * * *$ & $-0.260 * * *$ & $-0.265 * \cdots$ \\
\hline & $(0.047)$ & (0.045) & $(0.050)$ & $(0.050)$ & $(0.043)$ & $(0.043)$ & $(0.047)$ & $(0.047)$ & $(0.044)$ & (0.043) & $(0.039)$ & (0.039) \\
\hline \multirow[t]{2}{*}{ Control of comuption } & $0.189 * \cdots$ & $\bullet 0.215 * *$ & $\bullet 0.273 *$ & $0.200 * *$ & $\cdot 0.077^{* * *}$ & $0.053 * \cdots$ & $0.140 * \cdots$ & $0.145 * 0$ & -0.001 & $0.172 * *$ & $0.075 *$ & 0.005 \\
\hline & $(0.015)$ & $(0.017)$ & $(0.023)$ & $(0.024)$ & $(0.017)$ & $(0.020)$ & $(0.015)$ & $(0.015)$ & $(0.032)$ & $(0019)$ & $(0.035)$ & $(0.032)$ \\
\hline \multirow[t]{2}{*}{ Enforcing costracts } & $0.776 * \cdots$ & & $0.754 \cdots$ & & $-0.990 \%$ & & $-0.385 * \ldots$ & & $-2.043 * \cdots$ & & $-1.125 * \cdots$ & \\
\hline & $(0.082)$ & & $(0,137)$ & & (0.105) & & $(0.072)$ & & $(0.175)$ & & $(0.252)$ & \\
\hline \multirow[t]{2}{*}{ Sturting a business } & & $0.169 * \cdots$ & & $0.683 \cdots$ & & $0.273 \cdots$ & & $0.158 *$ & & $-1.031 * \cdots$ & & $-1.034 * \cdots$ \\
\hline & & (0.048) & & $(0066)$ & & (0.056) & & $(0.040)$ & & (0.076) & & (0.083) \\
\hline \multirow[t]{2}{*}{ Coestant } & $0.933 \cdots$ & $\cdot 3.301 \cdots$ & $\cdot 2.451 \cdots$ & $3334 \cdots$ & $-2.461 \cdots$ & $3.917 \cdots$ & -0.131 & $2250 \%$ & $3.388 \cdots \cdots$ & i393*... & -0.184 & $-1.668 \cdots$ \\
\hline & $(0.313)$ & $(0.165)$ & (0.509) & $(0.232)$ & $(0.432)$ & $(0.272)$ & $(0.282)$ & $(0.825)$ & $(0.634)$ & $(0.260)$ & $(0.911)$ & (0.289) \\
\hline N & 23,234 & 23,234 & 11,419 & $11, A 19$ & 16,427 & 16,427 & 18.226 & 18,226 & 14,640 & $14,6 \oplus 0$ & 15,203 & 15,203 \\
\hline R-squared & 0.42 & 0.42 & 0.47 & 0.46 & 0.36 & 0.36 & 0.27 & 0.26 & 0.54 & 0.55 & 0.43 & 0.45 \\
\hline
\end{tabular}

Notes: The following variables are expressed as logarithms in all regression models: share of expatriates, capital intensity, share of total fapanese investment in the sabsidiary and age. The estimation of each model includes dummy variables for each industry and each year of observation. Robust standard errors are in partenthesis. " significant at $10 \%$; $* *$ significant at $5 \%$; stimation of each model ignifican an $1 \%$.

Thirdly, Tables 5 and 6 exclude respectively China and Hong Kong and Singapore from the dataset. The reason to exclude China is that it hosts a relatively large number of subsidiaries for reasons that are not necessarily captured in the models in Tables 3 and 4. Excluding China in models (9) and (10) allows us to test for this. The results show that the signs remain the same as in model (7) in Table 4, but that the value of some coefficients changes. It decreases for the share of local partners in capital, which indicates that in China a higher share of local partners reduces the rate of expatriation to a greater degree than elsewhere. In model (9), the coefficient of 'control for corruption' is now statistically insignificant, which indicates that in combination with the 'enforcing contracts' variable the role of the 'control for corruption' variable in explaining expatriation is particularly relevant in the context of China's business environment, not in the context of other Asian countries.

Lastly, the small average size of subsidiaries in Hong Kong and Singapore may be related to the possibility that manufacturing firms have regional headquarters in those city states, but production operations in sub-subsidiary firms in respectively neighbouring China and Indonesia or Malaysia. Excluding Hong Kong and Singapore does not change the sign of the coefficients in models (11) and (12), compared with model (7) in Table 4. The only key change is that the 'control for corruption' variable is statistically insignificant in model (12). This indicates that in combination with the 'starting a business' variable, the role of the 'control for corruption' variable in explaining expatriation is particularly relevant in the cases of the business environment in Hong Kong and Singapore, not in the context of other Asian countries. 
In all, the signs of the coefficients remain the same as in model (7) in Table 4, which confirms Hypothesis (4). In other words, in countries with more risky business environments, subsidiaries of MNCs tend to rely to a greater degree on locally recruited senior staff rather than expatriates. This conclusion differs significantly from Gaur, Delios, and Singh (2007) who find that a greater institutional distance between home and host country leads firms to increase their reliance on expatriate managers. It confirms Ando and Paik (2013) who conclude the opposite. Arguably, the indicators of country risk in this study and of 'institutional distance' in other studies do not necessarily yield similar indications of distance between home and host countries. Nevertheless, both broadly point in the same direction. The key difference between this study and Gaur, Delios and Singh (2007) is how it accounts for capital, as explained above. As a consequence of properly accounting for changes in the real value of capital since the establishment of subsidiary companies, this study finds that capital intensity is positively correlated and highly statistically significant, which impacts on the statistical significance of the coefficients of other explanatory variables.

\section{Conclusion}

This paper shows that firm-specific factors, particularly capital intensity, the ownership share of parent firms in subsidiary firms and the age of the venture, together explain a very large part of the variation in the degree to which subsidiary companies depend on expatriates, and that in host countries with more risky business environments subsidiaries of MNCs tend to rely to a lesser extent on expatriates, and by implication to a greater degree on locally recruited senior staff. The paper shows that advancing age, as well as a higher degree of local participation reduces the dependence of a foreign subsidiary firm on expatriate employees.

Further research should address the question why firms do this. It can be hypothesised that business success in a host country with a higher degree of perceived risk depends on a superior understanding of the idiosyncrasies of the business environment of the host country and possibly on local connections, both of which locally recruited senior staff may have. It could also be that a parent company is reluctant to expose expatriates and their families to the difficulties of living in a host country with a higher degree of perceived risk. Either way, localisation of senior management is a strategy to minimise country risk. By controlling for firm-specific factors, the paper also finds that the capital intensity of production of a subsidiary venture is positively correlated with the degree of expatriation and that this variable actually explains a large part of it. Further research should explain why this is the case. It can be hypothesised that MNCs maintain expatriates in their foreign subsidiary ventures as a consequence of company strategies aimed at maximising control. The purpose of doing this is that a subsidiary firm needs to optimise its use of capital-intensive technologies, and also maximise the likelihood that it will be able to service its outside finance in the form of participations by parent firms as well as debt, especially if debt was guaranteed by parent MNCs. This will require data that allow the assessment of how Japanese foreign subsidiaries are financed.

Arguably, a shortcoming of this research is that it focuses on Japanese firms in an Asian context. Further research should also investigate whether the findings hold for non-Asian host countries with different business environments and levels of risk. Lastly, further research should compare the findings with those for earlier benchmark years to test whether Japanese firms have changed their expatriation strategies and assess the possible reasons for that. 


\section{References}

Ando, Naoki and Yongsun Paik. 2013. 'Institutional Distance, Host Country and International Business Experience, and the Use of Parent Country Nationals.' Human Resource Management Journal 23(1) 52-71.

Baruch, Yehuda and Yochanan Altman. 2002. 'Expatriation and Repatriation in MNCs: A Taxonomy.' Human Resource Management 41(2) 239-259.

Beamish, Paul W., Andrew Delios, and Donald J. Lecraw. 1997. Japanese Multinationals in the Global Economy. Cheltenham: Edward Elgar.

Belderbos, René A. and Mariëlle G. Heijltjes. 2005. 'The Determinants of Expatriate Staffing by Japanese Multinationals in Asia: Control, Learning and Vertical Business Groups.' Journal of International Business Studies 36(3) 341-454.

Beechler, Shon and Jong Zhuang. 1994. 'The Transfer of Japanese-Style Management to American Subsidiaries: Contingencies, and Competencies.' Journal of International Business Studies, 25(3) 467-491.

Boyacigiller, Nakiye. 1990. 'The Role of Expatriates in the Management of Interdependence, Complexity and Risk in Multinational Corporations.' Journal of International Business Studies, 21 (3) 358-381.

Chen, Edward K.Y. 1983. 'Factor Proportions of Foreign and Local Firms in Developing Countries: A Theoretical and Empirical Note.' Journal of Development Economics, 12: 267-274.

Click, Reid W. 2005. 'Financial and Political Risks in US Foreign Investment.' Journal of International Business Studies, 36(5) 559-575.

Delios, Andrew and Ingmar Björkman. 2000. 'Expatriate Staffing in Foreign Subsidiaries of Japanese Multinational Corporations in the PRC and the United States.' International Journal of Human Resource Management, 11(2) 278-293.

Downes, Meredith and Anisya S. Thomas. 2000. 'Knowledge Transfer through Expatriation: The UCurve Approach to Overseas Staffing.' Journal of Managerial Issues 12(2) 131-149.

Fang, Yulin, Guo-Liang Frank Jiang, Shige Makino, and Paul W. Beamish. 2010. 'Multinational Firm Knowledge, Use of Expatriates, and Foreign Subsidiary Performance.' Journal of Management Studies 47(1) 27-54.

Gaur, Ajai S., Andrew Delios, and Kulwant Singh. 2007. 'Institutional Environments, Staffing Strategies, and Subsidiary Performance.' Journal of Management 33(4) 611-636.

Gong, Yaping. 2003. 'Subsidiary Staffing in Multinational Enterprises: Agency, Resources, and Performance.' Academy of Management Journal 46(6) 728-739. doi: 10.2307/30040664

Jaussaud, Jacques, Johannes Schaaper, and Zhong-yu Zhang. 2001. 'The Control of International Equity Joint Ventures: Distribution of Capital and Expatriation Policies.' Journal of the Asia Pacific Economy 6(2) 212-231.

Jaussaud, Jacques and Johannes Schaaper. 2007. 'European and Japanese Multinational Companies in China: Organization and Control of Subsidiaries.' Asian Business \& Management 6(3) 223245.

Kawai, Norifumi and Roger Strange. 2014. 'Subsidiary Autonomy and Performance in Japanese Multinationals in Europe.' International Business Review 23(3) 504-515.

Keeley, Timothy Dean. 2001. International Human Resource Management in Japanese Firms: Their Greatest Challenge. Basingstoke: Palgrave.

Konopaske, Robert, Steve Werner, and Kent E. Neupert. 2002. 'Entry Mode Strategy and Performance: The Role of FDI Staffing.' Journal of Business Research 55(9) 759-770.

Legewie, Jochen. 2002. 'Control and Co-ordination of Japanese Subsidiaries in China: Problems of an Expatriate-Based Management System.' International Journal of Human Resource Management 13(6) 901-919.

METI. 2003. White Paper on International Trade 2003. Tokyo: Ministry of External Trade and Industry.

Oetzel, Jennifer M., Richard A. Bettis and Marc Zenner. 2001. 'Country Risk Measures: How Risky Are They?' Journal of World Business 26(2) 128-145.

Paik, Yongsun and Junghoon Derick Sohn. 2004. 'Expatriate Managers and MNC's Ability to Control International Subsidiaries: The Case of Japanese MNCs.' Journal of World Business 39(1) 6171. 
Peng, George Z. and Paul W. Beamish. 2014. 'MNC Subsidiary Size and Expatriate Control: Resource-Dependence and Learning Perspectives.' Journal of World Business 49(1) 51-62.

Qian, Li Hong and Andrew Delios. 2008. 'Internationalization and Experience: Japanese Banks' International Expansion, 1980-1998.' Journal of International Business Studies 39(2) 231-248.

Selmer, Jan, ed. 1995. Expatriates Management: New Ideas for International Business. Westport CT: Quorum.

Shiraki, Mitsuhide. 2007. 'Role of Japanese Expatriates in Japanese Multinational Corporations: From the Perspective of the Multinational Internal Labor Market.' Creation of New Contemporary Asian Studies Working Paper No.42. Tokyo: School of Political Science and Economics, Waseda University.

Tan, Danchi and J.T. Mahoney. 2006. 'Why a Multinational Firm Chooses Expatriates: Integrating Resource-Based, Agency and Transaction Cost Perspective.' Journal of Management Studies 43(3) 457-84.

Tōyō Keizai. 2000-2005. 海外進出企業総覧 Kaigai shushutsu kigyo soran 1999-2004 [Operations of Japanese-controlled firms in overseas markets]. Tokyo: Tōyō Keizai Shinpōsha.

Watson O'Donnell, Sharon. 2000. 'Managing Foreign Affiliates: Agents of Headquarters, or an Independent Network?' Strategic Management Journal 21(5) 525-548.

Wilkinson, Timothy. J., George Z. Peng, Lance Eliot Brouthers, and Paul W. Beamish. 2008. 'The Diminishing Effect of Cultural Distance on Subsidiary Control' Journal of International Management 14(2) 93-107.

Yoshihara, Hideki. 2005. 'Decline of Japan's Predominance in Asia.' In Japanese Firms in Transition: Responding to the Globalization Challenge, edited by Tom Roehl and Allan Bird, 243-260 Amsterdam: Elsevier.

Yoshihara, Hideki. 2008. 'Belated Changes in International Management of Japanese Multinationals.' Rikkyo Business Review 1(1) 4-15.

Widmier, Scott, Lance Eliot Brouthers, and Paul W. Beamish. 2008. 'Expatriate or Local? Predicting Japanese Subsidiary Expatriate Staffing Strategies.' International Journal of Human Resource Management 19(9) 1607-1621.

Zaheer, Srilata, Margaret Spring Schomaker and Lilach Nachum. 2012. Distance without Direction: Restoring Credibility to a Much-Loved Construct.' Journal of International Business Studies 43(1) 18-27. 